\title{
Biology and Management of Common Chickweed (Stellaria media) in Ornamental Crop Production'
}

\author{
Yuvraj Khamare, Chris Marble, Nathan Boyd, and Shawn Steed ${ }^{2}$
}

\section{Introduction}

Chickweed (Stellaria media) is a commonly found winter annual weed in Florida landscapes, container nurseries, home gardens, and other agricultural production systems. This article is written for green industry professionals and others to aid in the identification and management of chickweed in and around ornamental plants.

\section{Species Description}

\section{Class}

Dicotyledonous plant

\section{Family}

Caryophyllaceae (pink family)

\section{Other Common Names}

chickenwort, chickweed, common chickweed, winterweed

\section{Life Span}

Winter or cool-season annual

\section{Habitat}

Chickweed thrives in cool, moist, and shaded areas (Figure 1) as well as in nurseries and greenhouses. It is often found in cultivated fields, pastures, gardens, shady lawns, roadsides, and plantation crops and under trees and shrubs.

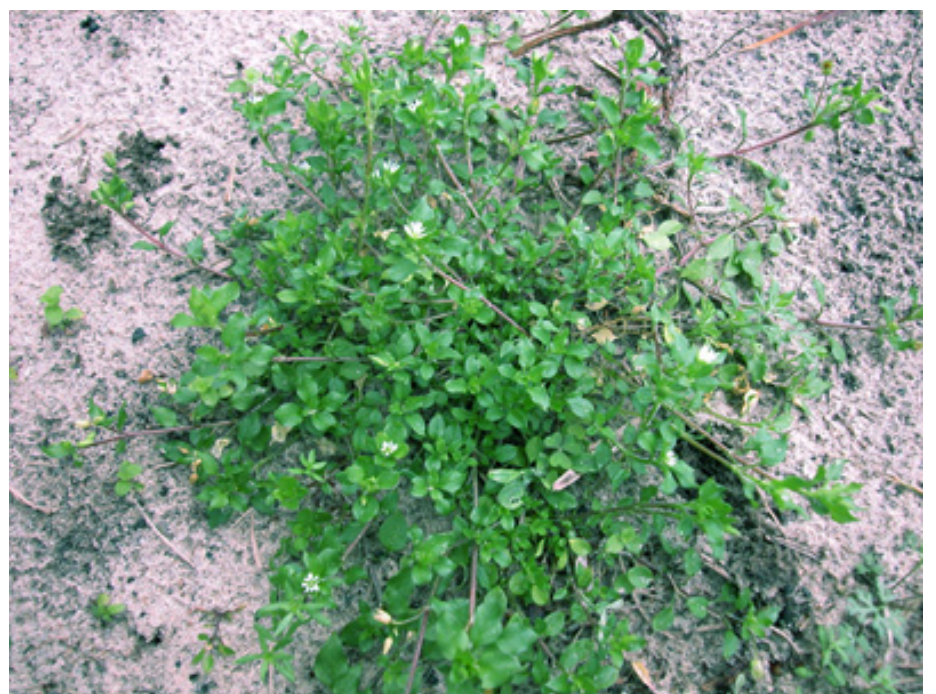

Figure 1. Stellaria media plant. Note the mat-forming branches. Credits: Annette Chandler, UF/IFAS

\section{Distribution}

Chickweed is native to Europe but has spread through much of the world. It is commonly found throughout North America, Europe, and Asia and is now one of the most widespread weeds in the world (Holm et al. 1977). Chickweed grows in a wide range of soils; it thrives in soils with high nitrogen levels and neutral $\mathrm{pH}$ (around 7.0), but it can grow across a wide range of soil $\mathrm{pH}$. In Florida, chickweed is most commonly found in the north and central parts of the state, but it can be found in south Florida as well (Wunderlin et al. 2019).

1. This document is ENH1313, one of a series of the Environmental Horticulture Department, UF/IFAS Extension. Original publication date October 2019. Visit the EDIS website at https://edis.ifas.ufl.edu for the currently supported version of this publication.

2. Yuvraj Khamare, graduate research assistant; Chris Marble, assistant professor, Environmental Horticulture Department, UF/IFAS Mid-Florida Research and Education Center; Nathan Boyd, associate professor, Horticultural Sciences Department, UF/IFAS Gulf Coast REC; and Shawn Steed, multi-county environmental horticultural Extension agent III, UF/IFAS Extension Hillsborough County; UF/IFAS Extension, Gainesville, FL 32611.

The Institute of Food and Agricultural Sciences (IFAS) is an Equal Opportunity Institution authorized to provide research, educational information and other services only to individuals and institutions that function with non-discrimination with respect to race, creed, color, religion, age, disability, sex, sexual orientation, marital status,

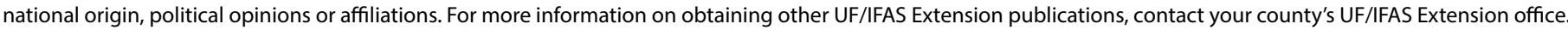
U.S. Department of Agriculture, UF/IFAS Extension Service, University of Florida, IFAS, Florida A \& M University Cooperative Extension Program, and Boards of County Commissioners Cooperating. Nick T. Place, dean for UF/IFAS Extension. 


\section{Growth Habit}

Chickweed is most commonly prostrate (low-growing along the ground) but in some environments can have an upright growth habit reaching over 12 inches in height.

\section{Seedling}

Seedlings are light or bright green in color. The seed leaves (cotyledons) have noticeable mid-veins and have a few fine hairs at the base of the leaf. The first few leaf pairs are oval to oblong-shaped with a taper to the tip (Figure 2).

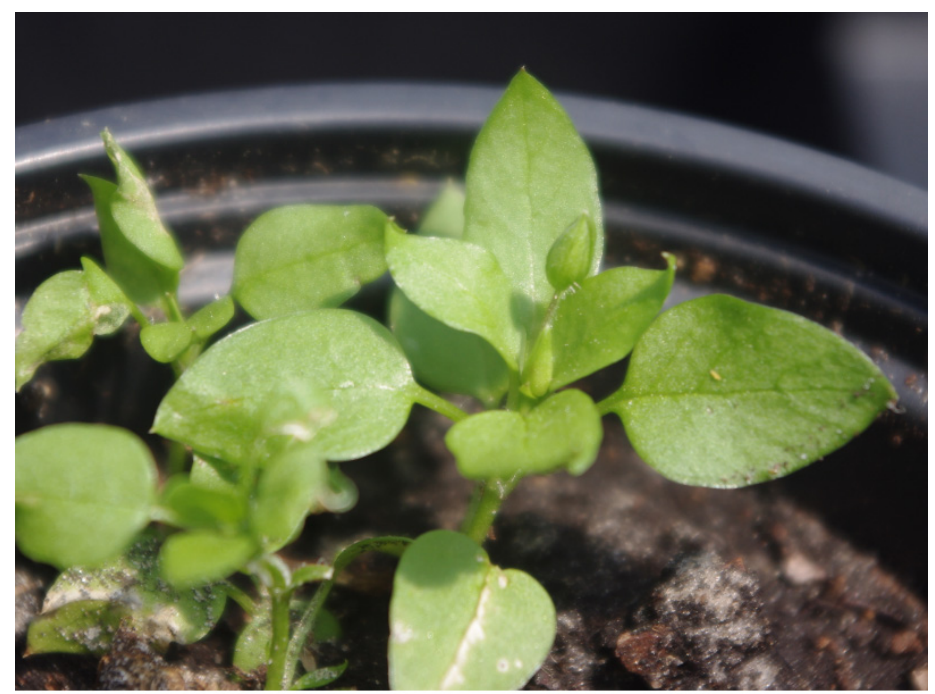

Figure 2. Stellaria media seedling.

Credits: Annette Chandler, UF/IFAS

\section{Shoot}

Stems are mostly branched and decumbent (laying down), growing 1.5-15 inches in length, and usually have a line of hairs (pubescence) down either side. Leaves are typically egg-shaped (ovate) with a pointy tip and may be hairless (glabrous) or have hairy margins at the base (Figure 3 ). The leaves are spaced evenly and are opposite to one another along the stem. Lower leaves are stalkless and smaller than the upper, stalked leaves (Sobey 1981).

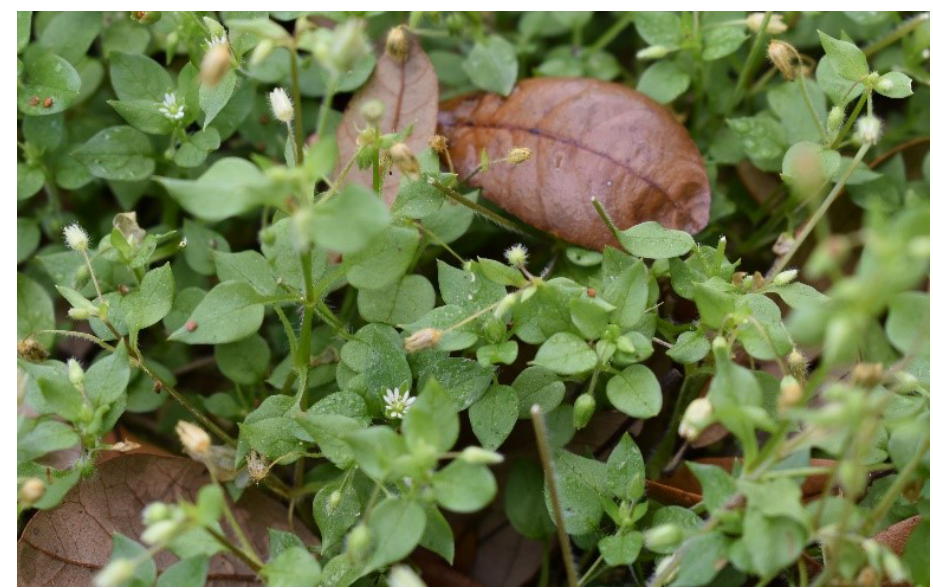

Figure 3. Stellaria media leaves. Note the smooth, ovate, and sharp tip. Credits: Annette Chandler, UF/IFAS

\section{Roots}

Roots are thin, white, and fibrous and may range from 1 to 9 inches in length with a shallow yellowish or white taproot. Stems that are in contact with the soil have the ability to root, which can cause further spread and increase chickweed's potential as a troublesome weed (Roberts and Stokes 1966).

\section{Inflorescence}

Chickweed may flower throughout the year in Florida depending on the environment it is growing in, but it typically grows and flowers from late fall throughout the spring (November through May). The first flowers may appear within 4 to 5 weeks after germination. The flowers are small and star-shaped (actinomorphic) with five white petals 0.1 to 0.2 inches wide when fully open. Chickweed often appears to have 10 petals due to the deep cuts or slits in the petals (Figure 4). Flowers occur as a loose cyme (a group of flowers where the growing points end in a flower).

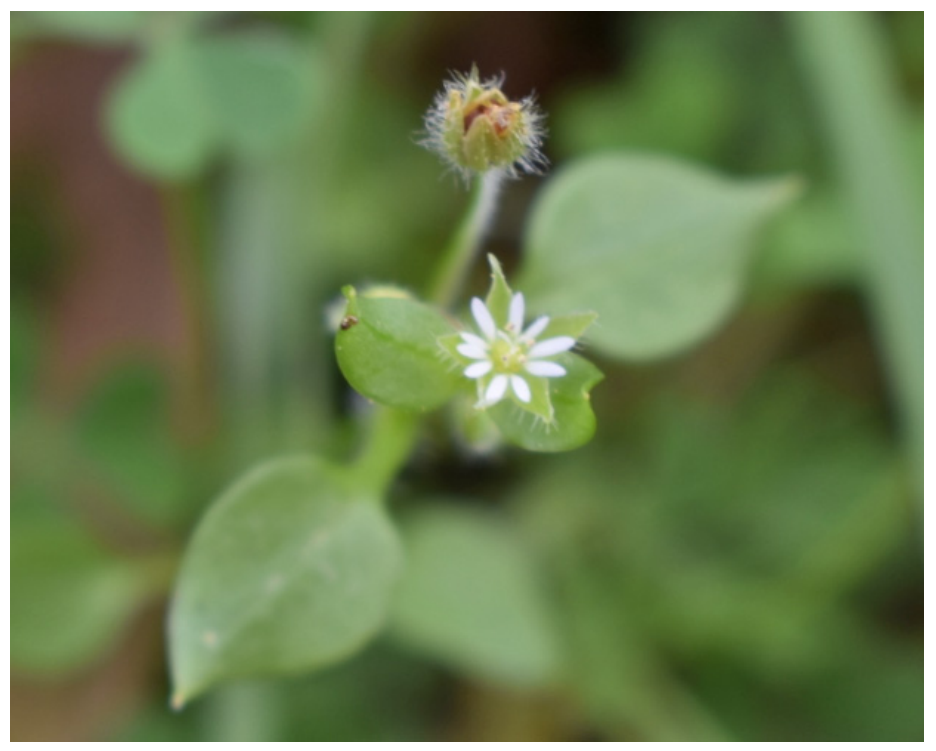

Figure 4. Stellaria media in flower (star-shaped flowers). Credits: Annette Chandler, UF/IFAS

\section{Fruits and Seeds}

The fruit is an egg-shaped capsule 0.16-0.26 inches long and breaks into six segments at maturity. The seeds are very small (about $1 / 25$ of an inch in diameter), reddish brown, rounded, and flat-topped or kidney-shaped with small hooks on the back. The seeds germinate best at the depth of $1 / 4$ to $1 / 2$ inches, with very few seeds germinating at depths more than one inch (Sobey 1981). The seeds are easily dispersed by wind, animals, humans, and equipment. They are also known to be dispersed long distances by ants or in the feces of pigs, horses, cattle, deer, sparrows, and quail. 


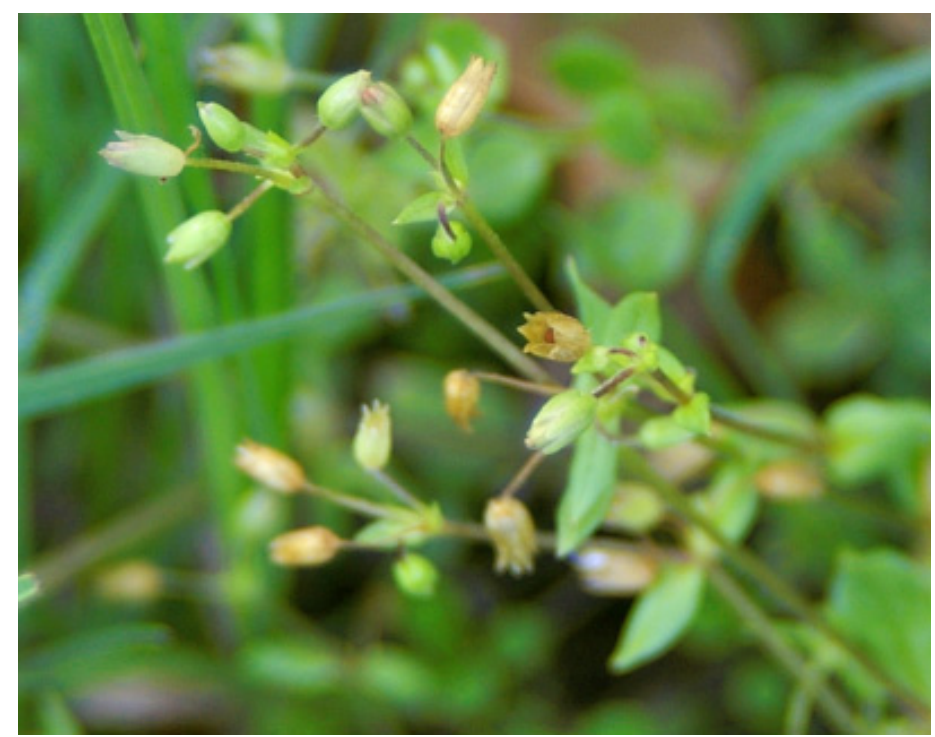

Figure 5. Stellaria media seed capsule.

Credits: Annette Chandler, UF/IFAS

\section{Similar Species}

Mouse-ear chickweed (Cerastium vulgatum) superficially looks like common chickweed. The flowers are very similar, but the petals are not deep when compared to $S$. media. Mouse-ear chickweed also has very hairy (pubescent) leaves, much more so than S. media does. The Stellaria genus group contains three closely related species: $S$. media, S. neglecta, and S. pallida. S. neglecta is distinguished by the bigger size of all its parts, while $S$. pallida is short-stalked and slender with pale-green leaves (Wunderlin et al. 2019).

\section{Plant Biology}

Stellaria media is a winter annual mostly found during fall, winter, and early spring. The optimal temperature range for seed germination is $54^{\circ} \mathrm{F}$ to $68^{\circ} \mathrm{F}$, but chickweed can tolerate lower temperatures. The seeds are highly viable and may remain viable for 60 years or more depending upon environment (Evans 1962). Each plant can produce 600-15,000 seeds. Chickweed flowers are short-lived and usually self-pollinated, but they may also be pollinated by bees or flies.

\section{Management}

The first step in any pest-management program is scouting fields for weeds. Scouting will enable you to determine which pest plants are present and plan control methods accordingly. It can be done by simply walking and recording the species encountered.

\section{Physical and Cultural Control}

Chickweed should be removed before it flowers. It is a copious seeder with a very short interval between germination to flowering (four to six weeks). If chickweed is an issue in a nursery, frequent hand weeding (every two to three weeks) will prevent further spread. In landscapes, light tillage or hoeing can be used to control emerged chickweed. In both nurseries and landscapes, organic mulch (pine straw, pine bark, wood chips, rice hulls, etc.) can provide control. In containers, mulch can be applied at depths of 1 to 1.5 inches, whereas 2- to 3 -inch depths can be applied in the landscape.

\section{Chemical Control}

The following are recommendations for chemically controlling common chickweed. However, before applying herbicides of any type, be sure to check the expiration date, wear safety equipment, and thoroughly read and follow all label instructions.

\section{PREEMERGENCE HERBICIDES}

Chickweed is generally controlled well with preemergence herbicides. In general, Weed Science Society of America (WSSA) group 3 herbicides such as prodiamine (Barricade), pendimethalin (Pendulum), dithiopyr (Dimension), and others that include one of those active compounds such as FreeHand, Gemini, Fortress, $\mathrm{OH} 2$, Biathlon, and others offer good control. Other herbicides such as those that contain flumioxazin (Broadstar, SureGuard), indaziflam (Marengo, Specticle) and dimethenamid-P (Tower) are also effective. A list of commonly used preemergence herbicides and their efficacy on chickweed is included in Table 1.

\section{POSTEMERGENCE HERBICIDES}

Most broad-spectrum herbicides labeled for use in nurseries or landscapes offer control of chickweed. Systemic herbicides such as glyphosate can be used to control large mature chickweed that is flowering or has stems greater than 10 inches in length. Contact-type herbicides such as glufosinate (Finale), diquat (Reward), pelargonic acid (Scythe), and others will control small plants (4 to 6 inches in length) and may also provide control of larger plants, but two applications may be needed for heavy infestations. A list of postemergence herbicides labeled for use in nurseries, landscapes, and greenhouses is available in EDIS publication ENH95, Postemergence Herbicides for Use in Ornamentals (http://edis.ifas.ufl.edu/wg059). 


\section{References}

Bond, W., and R. Turner. 2004. The Biology and Nonchemical Control of Common Chickweed (Stellaria media L.). United Kingdom: Henry Doubleday Research Association

CAB International (CABI). 2019. "CABI Invasive Species Compendium Online Data Sheet. Stellaria media." CABI Publishing. https://www.cabi.org/ISC

Evans, S. A. 1962. Weed Destruction: A Farmer's and Student's Guide. Oxford, UK: Blackwell Scientific Publications.

Holm, L. G., D. L. Plucknett, J. V. Pancho, J. P. Herberger. 1977. The World's Worst Weeds: Distribution and Biology. Honolulu, Hawaii, USA: University Press of Hawaii.

Neal, J. C., and J. F. Derr. 2005. Weeds of Container Nurseries in the United States. Raleigh, NC: North Carolina Assoc. of Nurserymen, Inc

Roberts, H. A., and F. G. Stokes. 1966. "Studies on the Weeds of Vegetable Crops. VI. Seed Populations of Soil under Commercial Cropping." Journal of Applied Ecology 3: 181-190.

Sobey, D. G. 1981. “Stellaria media (L.) Vill.” Journal of Ecology 69(1): 311-335.

Wunderlin, R. P., B. F. Hansen, A. R. Franck, and F. B. Essig. 2019. "Atlas of Florida Plants." Accessed May 7, 2019. http:// florida.plantatlas.usf.edu/ 
童

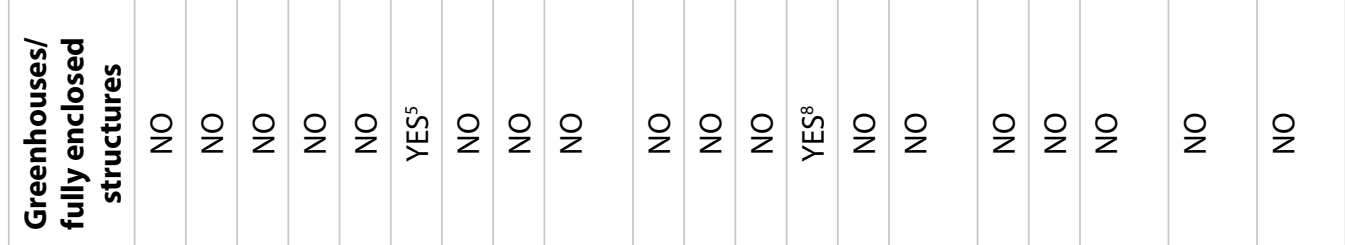

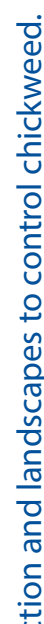

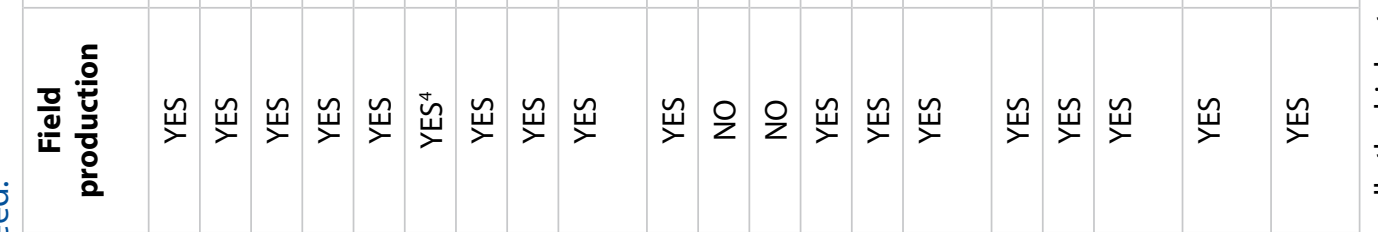

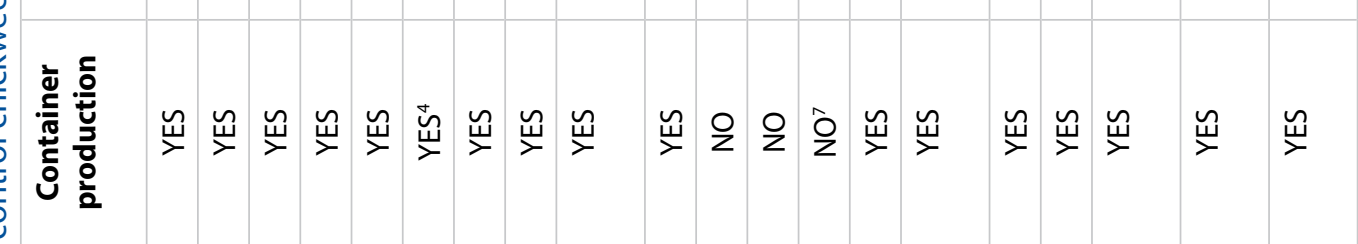

.

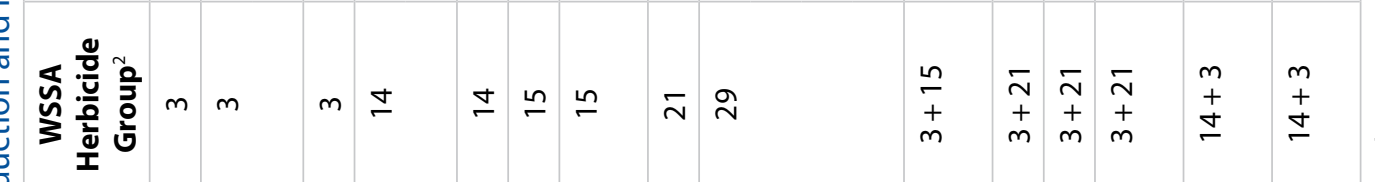

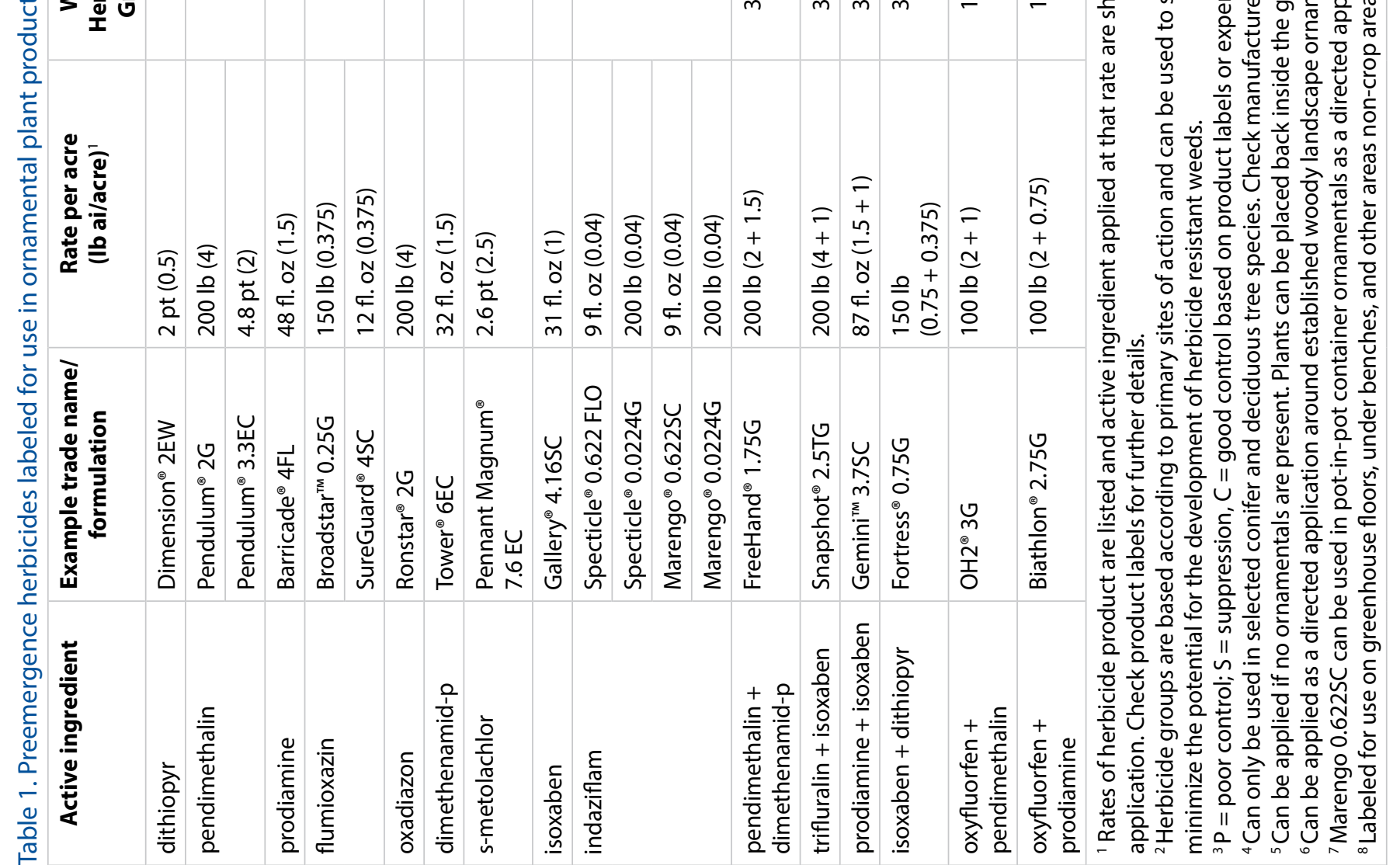

